\title{
The Use of a Modest Alcohol Meter
}

\author{
Maria Agatha Hertiavi1,2, Putut Marwoto³, Retno Sri Iswari3, Edy Cahyono³ \\ ${ }^{1}$ Student of Doctoral Science Education Postgraduate Program, Universitas Negeri Semarang, Semarang, Indonesia \\ ${ }_{2}^{2}$ Physics Education Study Program, Universitas Pattimura, Ambon, Indonesia \\ ${ }^{3}$ Science Education Postgraduate Program, Universitas Negeri Semarang, Semarang, Indonesia
}

DOI: $\underline{10.29303 / \text { ippipa.v7iSpecialIssue.841 }}$

\section{Article Info}

Received: July 23rd, 2021

Revised: November 23rd, 2021

Accepted: November 27th, 2021

\begin{abstract}
During the pandemic, healthy life behavior is needed in an attempt to reduce the transmission risk. One of them could be done by washing hands. Various human activities may not allow them to wash their hands frequently, for example, using hand sanitizer to wash hands. Hand sanitizer or Isopropyl based alcohol are recommended materials by WHO to clean bacteria on hands. Storing hand sanitizer for a longer time leads to inaccurate quality of the hand sanitizer to the written quality on the package. A simple alcohol meter is designed to test the liquid percentage of hand sanitizer or Isopropyl Alcohol (IPA) based alcohol. The required materials are easy to get from the surrounding environment. Thus, this device could be established at home without ignoring the health protocol. Although it has strength IPA-based alcohol or hand sanitizer is also risky if it is incorrectly used.
\end{abstract}

Keywords: alcohol meter; hand sanitizer; isopropyl alcohol

Citation: Hertiavi, M. A., Marwoto, P. ., Iswari, R. S. ., \& Cahyono, E. . (2021). The Use of a Modest Alcohol Meter. Jurnal Penelitian Pendidikan IPA, 7(SpecialIssue), 126-130. https://doi.org/10.29303/jppipa.v7iSpeciallssue.841

\section{Introduction}

Hand sanitizer is a hand wash with antibacterial to hinder and kill bacteria (Sari, Retno\& Isadiartuti, 2006). Two types of hand sanitizer are found: nonalcohol and alcohol-based hand sanitizer (Golin et al., 2020). Other types of hand sanitizer are gel and spray hand sanitizer. Hand sanitizer is produced to keep hands clean and prevent infectious spread (Hayat \& Munnawar, 2016). Alcohol is mostly used as an antiseptic or disinfectant to disinfect clean skin surfaces. However, it is not recommended for injured skins. Alcohol can also irritate skins. It is also flammable and rises digestive tract inflammation virus infection. Thus, there is a notion to use natural materials to reduce health risks (Cahyani, 2014). Centers for Disease Control and Prevention (CDC), the United States of America, recommends the effective alcohol content to prevent microbes. It is between 60 $65 \%$. Isopropyl Alcohol (IPA) can be found in the drugstore. It is effective to kill microorganisms than ethanol. Among the alcohol-based formulations, ethanol has lower skin irritants. Isopropyl Alcohol for antiseptic should be between $50-95 \%$. This substance is flammable and irritates skins when used exaggeratedly (Purwati, 2016). During the pandemic, hand sanitizer is needed to prevent bacteria. It is sold freely in the market in various brands and concentrations. As consumers, we have to be aware of alcohol concentration in hand sanitizers. The concentration should be based on CDC recommendations. IPA easily evaporates and makes the alcohol concentration dynamically changes. Thus, a device to measure the factual IPA concentration is needed. Analysis of ethanol and IPA content could be done with an Alcohol meter. It is mostly used to measure alcohol content in liquor. The device has a mechanism to measure based on the mixed density between alcohol and water. The upper part of the device shows an alcohol content scale. The device will sink and the water threshold shows the alcohol content in the solution. The measurement of ethanol content is commenced after the destination

\footnotetext{
*Email: agathahertiavi@students.unnes.ac.id
} 
process. It is to determine the alcohol content of the fermented product in volume percentage ( $\% \mathrm{abv})$.

Alcoholmeter has a similar mechanism to the hydrometer. A hydrometer is a floating pipe or known as a dipped hydrometer. It is a hydrometer based on Archimedes law. Given the length of the plastic pipe is $L(\mathrm{~m})$ with weight $w l(\mathrm{~g})$ floating on the water with the water density of $\rho_{1}\left(\mathrm{~g} / \mathrm{cm}^{3}\right)$.

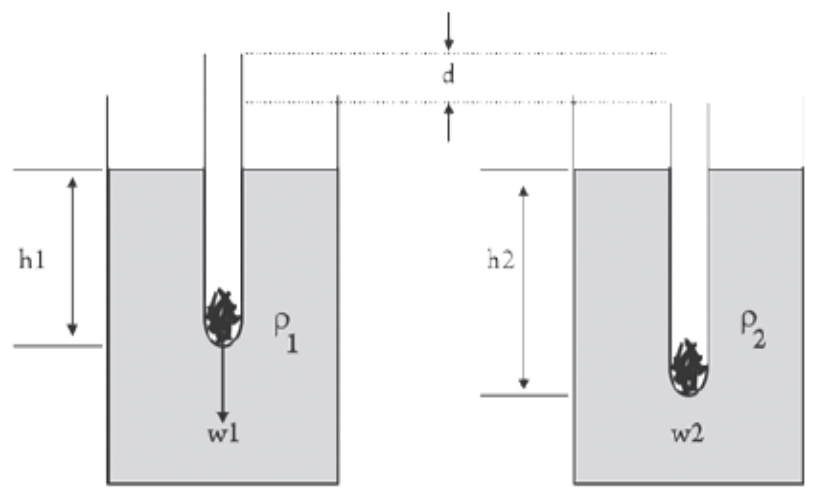

Figure 1. Hydrometer Working Principle

Given the pipe dipped into a liquid with a density of $\rho_{1}\left(\mathrm{~g} / \mathrm{cm}^{3}\right)$. Then, it is dipped into a liquid substance with a density of $\rho_{2}\left(\mathrm{~g} / \mathrm{cm}^{3}\right)$. In figure $1(\mathrm{~A})$, the height of the floating dipped pipe is $h_{1}$. The removed water volume of the tube is

$V_{1}=\pi r^{2} h_{1}$

The removed water weight is

$W_{1}=\pi r^{2} h_{1} \rho_{1} g$

In figure $19 \mathrm{~B}$ ), the height of the floating dipped pipe is $\mathrm{h}_{1}$. The removed water volume of the tube is

$V_{2}=\pi r^{2} h_{2}$

The removed water weight is

$W_{2}=\pi r^{2} h_{2} \rho_{2} g$

Assume that $\rho_{1}\left(\mathrm{~g} / \mathrm{cm}^{3}\right)$ is pure water. It is $\rho_{1}=1$ $\mathrm{g} / \mathrm{cm} 3$. To determine the $\rho_{2}\left(\mathrm{~g} / \mathrm{cm}^{3}\right)$, it is $\mathrm{w} 1=\mathrm{w} 2$ (constant, no being added or subtracted while being removed to substance 2), thus $\rho_{2}\left(\mathrm{~g} / \mathrm{cm}^{3}\right)$ is

$\rho_{2}=\frac{\rho_{1} h_{1}}{h_{2}}$

for $h_{2}>h_{1}$ so $h_{2}=h_{1}+d$, for lower substance density than water density

$\rho_{2}=-\frac{\rho_{1} h_{1}}{h_{2}}$

for $h_{2}>h_{1}$ so $h_{2}=h_{1}+d$, for higher substance density than water density

\section{Method}

This research is experimental research to produce a simple alcohol meter used to measure alcohol concentration in liquid material hand sanitizer sold in the market. The procedures to create an alcohol meter. Materials and Equipment are straw, measuring cylinder, small nails, basil seeds, waterproof markers, plasticine, ruler

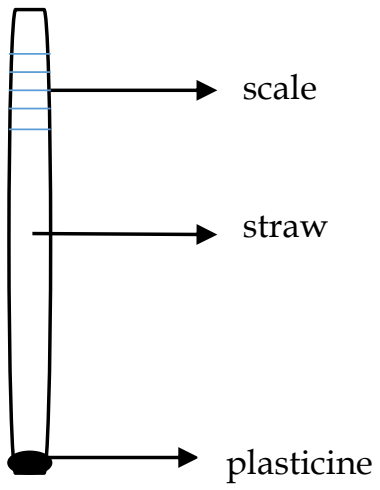

Figure 2. Modest Alcohol Meter

\section{Procedures to Create}

Prepare the straw and close one of the tips with plasticine. Fill the part of the straw with several nails and basil seeds. Dip them into the water until the straw floats as shown below.

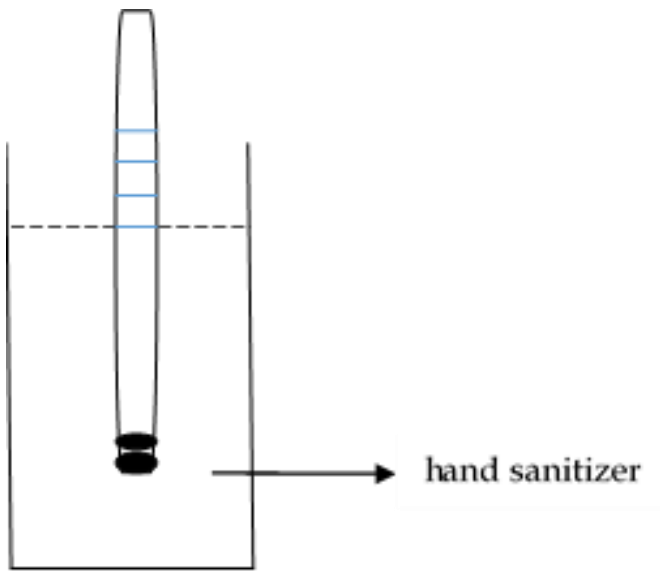

Figure 3. Alcohol Meter in Liquid

\section{The Experiment and Implementation}

Pour pure water or equates and alcohol, each of them, into the measuring cup. Mark the pure water with a scale of $1 \mathrm{~g} / \mathrm{cm}^{3}$ or $1000 \mathrm{~kg} / \mathrm{m}^{3}$. Then, dip it into alcohol and mark it with a marker. Calibrate the IPA percentage on the device by using the alcohol meter borrowed from the laboratory. 


\section{Result and Discussion}

From the experiment, the obtained data are shown in Table 1.

Table 1. Test Result

\begin{tabular}{llll}
\hline No & Hand sanitizer & $\begin{array}{l}\text { Written on the } \\
\text { Package (\%) }\end{array}$ & $\begin{array}{l}\text { Alcohol Meter } \\
\text { Test (\%) }\end{array}$ \\
\hline 1 & A & 60 & 55 \\
2 & B & 70 & 70 \\
3 & C & 80 & 70 \\
4 & D & 70 & 60 \\
5 & E & 70 & 70 \\
\hline
\end{tabular}

The alcohol percentage test was used to compare the written percentage on the package and the reexamination with the created alcohol meter. Table 1 shows several hand sanitizer or IPA-based alcohol did not show the actual percentage after being tested. Isopropyl Alcohol (IUPAC Propan-2-ol; also called Isopropanol or 2-Propanol) is an uncolored and flammable chemical substance $\left(\mathrm{CH}_{3} \mathrm{CHOHCH}_{3}\right)$ with a strong odor. As an isopropyl cluster, correlated to hydroxyl, this simple substance from secondary alcohol has atomic alcohol carbons attached to two other carbon atoms. It is a structural 1-propanol ethyl methyl ether isomer. It is used to create various domestic industrial chemical materials and is a common material for antiseptic, disinfectant, and detergent. Isopropyl alcohol cannot be mixed with water, ethanol, ether, and chloroform. This substance dissolves ethylcellulose, polyvinyl butyrate, oils, alkaloids, and natural resins. It is different from ethanol or methanol, this substance cannot be mixed in saline solution but it can be separated from the liquid solution by adding salt, such as sodium chloride. This process is called curing, causing the isopropyl alcohol to be concentrated and separated into different layers. Isopropyl alcohol is used as a hybrid solvent in a Meerwein-Pondorf-Verley reduction, the other hydrogenation reaction. This substance can be converted into 2-bromopropane by using phosphorus tribromide or dehydration of heated sulfate acid of propene. As most alcohols do, isopropyl alcohol reacts with the active metal, such as potassium. It forms alkoxides, called isopropoxides the aluminum reaction (initiated by mercury tracer) is used to prepare the isopropoxide catalyst. Indirect hydration reacts to propene sulfuric acid and forms sulfuric ether mixtures. This process can use low-quality propene, dominantly found in the United State of America. This process is done by providing isopropyl alcohol from 1propanol because adding water or propene sulfuric acid is based on Markovnikov law. Then, the steam Esther hydrolysis produces isopropyl alcohol, distilled. Di-isopropyl ether is a significant side product of this process. It is a recycled product in the process of hydrolysis, providing the demanded product. Isopropyl alcohol also dissolves various non-polar compounds. It also quickly evaporates. It has almost zero oil trace than ethanol and is relatively non-toxic than the alternative solvents. Therefore, it is broadly used as a solvent and liquid cleanser, especially to dissolve oil. Along with ethanol, n-butane, methanol, the alcohol solvent group consist of 6.400 .00 tons used for solvent in the world during 2011. Alcohol, hand cleanser, and disinfectant usually have 60 until 70\% isopropyl alcohol or ethanol solution in water. Water is needed to open the bacteria membranes. Thus, it needs isopropyl alcohol as the opener. A percentage of $75 \%$ $\mathrm{v} / \mathrm{v}$ solution in water can be used as hand sanitizer. Isopropyl alcohol is used as a water drier to prevent external otitis.

In 2015, WHO with Model List of Essential, recommended $80 \%$ ethanol and $75 \%$ isopropyl alcohol as a disinfectant category? Alcohol-based hand cleanser. Ethanol with $60 \%$ until $85 \%$ seemed effective to kill viruses than isopropanol $(60 \%-80 \%)$ and $n-$ propanol $(60 \%-80 \%)$ (Gold, 2018). A study with alcohol-based formulation recommended by $\mathrm{WHO}$ also showed strong virucidal. It functions as the appearing pathogen, included ZIKV, EBOV, SARS-CoV, and MERS-CoV (Siddharta et al., 2017). In another study in Germany, ethanol with a concentration of $42.6 \%$ could destroy the SARS coronavirus and MERS coronavirus in 30 seconds (Kampf, 2018). Isopropyl alcohol is mostly used as applied alcohol and mixed with other hand cleanser products. It evaporates quickly on the skin and provides a chilling sensation. Although it is safe for the skin, isopropyl alcohol is not safe to be drunk and so does ethanol. When an individual swallows the alcohol, intentionally or unintentionally, the reaction on the body can be seen right at that time or several hours later. The possible reactions are such as abdominal pain, disorientation, headache, breathing difficulty, blood pressure decrease, tachycardia, unclear speaking, and nausea and vomiting, having inflammation sensation in the throat, dysfunctional reflexes.

CDC recommends washing hands with soap and water when it is possible. It is because washing hands can reduce all types of bacteria and chemical substances on hands (Hadaway, 2020). When there is no soap, a hand cleaner with at least $60 \%$ ethanol or $70 \%$ isopropyl alcohol can non-activate the virus genetically with identic features with COVID-19. Several epidemiology studies showed the potentials of reducing infection transmission of respiratory and colon tracts by using hand cleansers (Fendler et al., 2002; Lopez et al., 2013; Prazuck et al., 2010). 
Tamimi et al., (2015) showed using hand sanitizer with alcohol materials could decrease infection risk by respiratory virus and enteric, such as rotavirus, rhinovirus, and norovirus even when washing hands is done regularly. Alcohol-based hand cleansers had been used as an effective alternative for washing hands and preventing bacteria and virus infections. It makes one of the crucial protocols to reduce the health care burden (Boyce \& Pittet, 2002; Pittet et al., 2009). According to the United States Food and Drug Administration (US, FDA), in 30 seconds until 60 seconds, hand sanitizer can directly reduce the number of bacteria (Chen et al., 2011) (Chen, 2011). According to the World Health Organization, "the applicable materials and time-efficient materials, containing alcohol (liquid, gel, or foam), are designed to be applied on hand to non-activated the microorganism or inhibit their growth temporarily". The availability may contain one or more alcohol types and other active substances with excipients and humectants (Greenaway et al., 2018). The Effectiveness of a cleaner should be applied on hands and free from soils, dirt, blood, and lubricants. A hand cleanser is not an alternative for washing hands. Contrary, it is actually an excellent habit to be done along with washing hands with soap (Golin et al., 2020). Research from (Rahmadani et al., 2021) shows that parents also play a role in their children's learning during a pandemic where washing hands is a must.

Making alcohol meters can be applied to science learning. Guided inquiry methods may be suitable for such learning. Students will practice making an alcohol meter with the guide that has been given. After that, students can also make concept maps of anything related to the alcohol meter, whether from physics, chemistry, or biology. The results of the study (Artayasa et al., 2021) explain that guided inquiry learning with the help of concept maps will improve students' scientific literacy.

\section{Conclusion}

The manufactured alcohol meter could be used to examine the hand sanitizer percentage or the IPAbased alcohol percentage. Several hand sanitizer and IPA-based alcohol in the markets showed a lower percentage as suggested by the written text on the package. It made the ineffective use of hand sanitizer to wash hands. Although IPA is useful and used as a hand sanitizer IPA also has weaknesses or risks when it is inaccurately used for daily life.

\section{Acknowledgments}

The authors gratefully acknowledge all participants.
This study does not use any funding from any institution and has no conflict of interest.

\section{References}

Artayasa, I. P., Merta, I. W., \& Hadiprayitno, G. (2021). The Effects of Guided Inquiry Learning with the Assistance of Concept Maps on Students ' Scientific Literacy. Jurnal Penelitian Pendidikan IPA, $7(2)$, 232-268.

https://doi.org/10.29303/jppipa.v7i2.692

Boyce, J. M., \& Pittet, D. (2002). Guideline for Hand Hygiene in Health-Care Settings. Recommendations of the Healthcare Infection Control Practices Advisory Committee and the HICPAC/SHEA/APIC/IDSA Hand Hygiene Task Force. Society for Healthcare Epidemiology of America/Association for Professionals in Infection Control/Infectious Diseases Society of America. MMWR. Recommendations and Reports: Morbidity and Mortality Weekly Report. Recommendations and Reports, 51(RR-16), 1-45, quiz CE1-4. Retrieved from: https://pubmed.ncbi.nlm.nih.gov/12418624/

Cahyani, N. (2014). Daun Kemangi (Ocinum Cannum) Sebagai Alternatif Pembuatan Handsanitizier. KEMAS: Jurnal Kesehatan Masyarakat, 9(2), 136-142. doi:https:// doi.org/10.15294/ kemas.v9i2.2843

Chen, Y.-C., Sheng, W.-H., Wang, J.-T., Chang, S.-C., Lin, H.-C., Tien, K.-L., Hsu, L.-Y., \& Tsai, K.-S. (2011). Effectiveness and limitations of hand hygiene promotion on decreasing healthcareassociated infections. PloS One, 6(11), e27163. https://doi.org/10.1371/journal.pone.0027163

Fendler, E. J., Ali, Y., Hammond, B. S., Lyons, M. K., Kelley, M. B., \& Vowell, N. A. (2002). The impact of alcohol hand sanitizer use on infection rates in an extended care facility. American Journal of Infection Control, 30(4), 226-233. https://doi.org/10.1067/mic.2002.120129

Golin, A. P., Choi, D., \& Ghahary, A. (2020). Hand sanitizers: A review of ingredients, mechanisms of action, modes of delivery, and efficacy against coronaviruses. American Journal of Infection Control, $48(9)$, 1062-1067. https://doi.org/10.1016/j.ajic.2020.06.182

Greenaway, R. E., Ormandy, K., Fellows, C., \& Hollowood, T. (2018). Impact of hand sanitizer format (gel/foam/liquid) and dose amount on its sensory properties and acceptability for improving hand hygiene compliance. The Journal of Hospital Infection, 100(2), 195-201. https://doi.org/10.1016/i.jhin.2018.07.011

Hadaway, A. (2020). Handwashing: Clean Hands Save Lives. Journal of Consumer Health on the Internet, 
24(1),

43-49.

https://doi.org/10.1080/15398285.2019.1710981

Hayat, A., \& Munnawar, F. (2016). Antibacterial Effectiveness of Commercially Available Hand Sanitizers. International Journal of Biology and Biotechnology, 13(3), 427-431.

Kampf, G. (2018). Efficacy of ethanol against viruses in hand disinfection. The Journal of Hospital Infection, 98(4), https://doi.org/10.1016/j.jhin.2017.08.025

Lopez, G. U., Gerba, C. P., Tamimi, A. H., Kitajima, M., Maxwell, S. L., \& Rose, J. B. (2013). Transfer efficiency of bacteria and viruses from porous and nonporous fomites to fingers under different relative humidity conditions. Applied and Environmental Microbiology, 79(18), 5728-5734. https://doi.org/10.1128/AEM.01030-13

Pittet, D., Allegranzi, B., \& Boyce, J. (2009). The World Health Organization Guidelines on Hand Hygiene in Health Care and their consensus recommendations. Infection Control and Hospital Epidemiology, 30(7), 611-622. https://doi.org/10.1086/600379

Prazuck, T., Compte-Nguyen, G., Pelat, C., Sunder, S., \& Blanchon, T. (2010). Reducing gastroenteritis occurrences and their consequences in elementary schools with alcohol-based hand sanitizers. The Pediatric Infectious Disease Journal, 29(11), 994-998. Retrieved from: https://pubmed.ncbi.nlm.nih.gov/21046699/

Purwati, L. S. (2016). Efektivitas Penggunaan Bioetanol dari Limbah Pulp Kakao ( Theobroma cacao L .) terhadap Lama Pembakaran Kompor Bioetanol. Jurnal Sains Dan Seni ITS, 5(1), 2016. https://doi.org/10.12962/j23373520.v5i1.15389

Rahmadani, D., Chastanti, I., \& Harahap, D. A. (2021). Parents' Role in Biology Learning During the Covid 19 Pandemic. Jurnal Penelitian Pendidikan IPA, 7(2), 137-172. https://doi.org/10.29303/jppipa.v7i2.583

Sari, Retno\& Isadiartuti, D. (2006). Studi efektivitas sediaan gel antiseptik tangan ekstrak daun sirih ( Piper betle Linn .) betle Linn extract in hand gel antiseptic preparation. Majalah Farmasi Indonesia, 17(4), 163-169. [Indonesian]

Siddharta, A., Pfaender, S., Vielle, N. J., Dijkman, R., Friesland, M., Becker, B., Yang, J., Engelmann, M., Todt, D., Windisch, M. P., Brill, F. H., Steinmann, J., Steinmann, J., Becker, S., Alves, M. P., Pietschmann, T., Eickmann, M., Thiel, V., \& Steinmann, E. (2017). Virucidal Activity of World Health Organization-Recommended Formulations Against Enveloped Viruses, Including Zika, Ebola, and Emerging Coronaviruses. The Journal of Infectious Diseases, 215(6), 902-906. https://doi.org/10.1093/infdis/jix046

Tamimi, A. H., Maxwell, S., Edmonds, S. L., \& Gerba, C. P. (2015). Impact of the use of an alcohol-based hand sanitizer in the home on reduction in probability of infection by respiratory and enteric viruses. Epidemiology and Infection, 143(15), 33353341.

https://doi.org/10.1017/S0950268815000035 